\title{
Responsabilidade Social nas Organizações de Trabalho: Benevolência ou Culpa?
}

Social responsability on work organizations: Benevolence or guilty?

Maria de Lurdes

Costa Domingos

Universidade

Estadual do

Rio de Janeiro
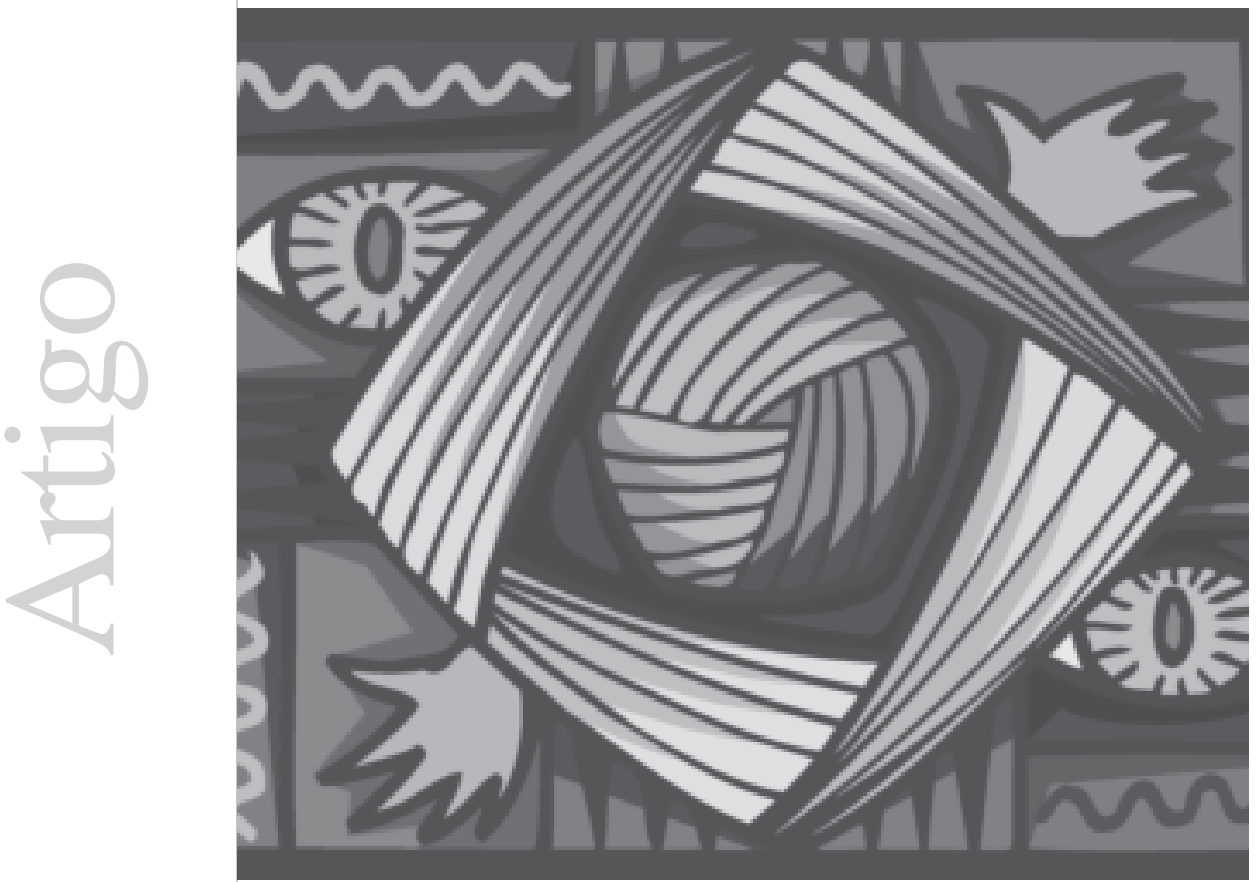


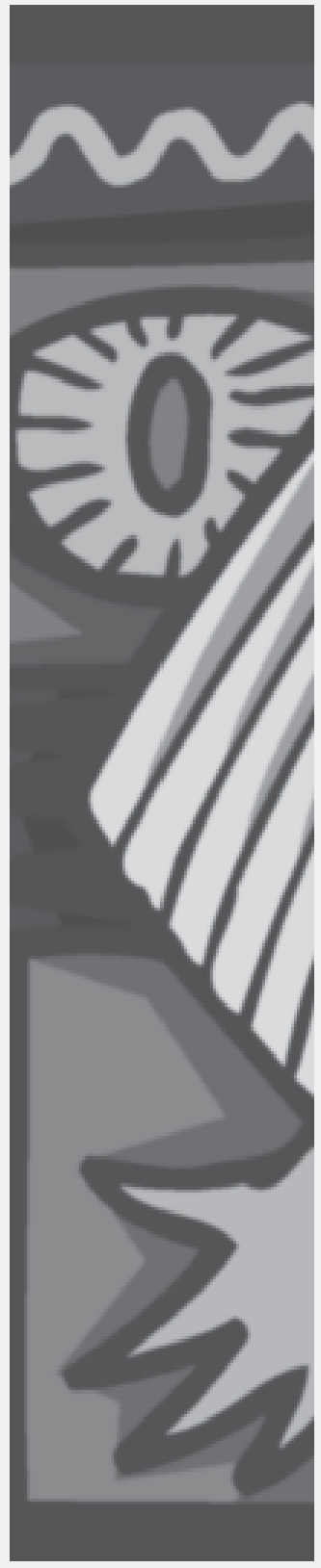

Resumo: A responsabilidade social das organizações compreende ações concretas expostas publicamente para anunciar uma nova postura dos dirigentes dos sistemas de produção frente às contradições e às tensões provocadas pelo capitalismo na sociedade. A partir dos conhecimentos da psicossociologia, nosso objetivo é refletir sobre a emergência desse tema para além do discurso positivista tradicional. Primeiramente analisaremos o assunto como parte da "nova ordem social" afirmada com a globalização. Nesse sentido, consideraremos a importância de observá-la em sua complexidade, compreendida, simultaneamente, enquanto ordem e desordem, racionalidade e subjetividade do sistema capitalista que a criou. Posteriormente, destacaremos a responsabilidade social nas organizações, reveladora da sua preocupação com a sustentabilidade social, mas também como meio de remissão da culpa pela destruição que o sistema produtivo impõe à imensa maioria da humanidade.

Palavras-chave: psicossociologia, responsabilidade social corporativa, organizações de trabalho e culpa.

Abstract:The social responsibility of organizations includes concrete actions publicly displayed to announce a new position of the controllers of the production systems facing the contradictions and tensions provoked by capitalism in society. From a psychosociology viewpoint, our objective is to think over the emergency of this subject beyond the traditional positivist discourse. Firstly, we will analyze the subject as part of a "new social order" affirmed with globalization. In this sense, we will consider the importance of understanding it in its complexity, as order and chaos simultaneously, rationality and subjectivity of the capitalist system that created it. Later, we will highlight the social responsibility in organizations, as a revelation of their concern about social sustainability, but also as a remission of guilt for the destruction that the productive system imposes to the immense majority of humanity.

Key words: psychosociology, corporate social responsibility, work organizations, guilt. 
A globalização é um fenômeno bastante discutido atualmente. A "nova ordem global" é palco de contradições e de tensões que abrem as entranhas do mundo para um grande espetáculo. Nele, desfilam redefinições sociais, políticas, culturais e econômicas, ao mesmo tempo em que se reformam espaços e temporalidades e aumentam as desigualdades sociais e econômicas entre os povos. Estamos suspensos entre o mito de uma mundialização mais justa e segura para a humanidade e a realidade que denuncia o fosso entre as diferenças, cada vez mais acentuadas. Criamos novos empregos, direcionados pela tecnologia, mas alimentamos o desgaste social, econômico, político e cultural dos povos contemporâneos, enredados por um sistema homogêneo de comunicação e de produção. Assistimos, simultaneamente, à fúria tecnicista que expande a comunicação entre as nações e que promove a redução da vida planetária. Observamos, incrédulos e extasiados, a expansão mundial do sistema capitalista de produção. Diante da crise das instituições tradicionais, o mercado produtivo privado surge como único espaço de identidade pessoal e reduz a heterogeneidade de interação social da humanidade.

Obviamente, devido à nossa onipotência, por benção, ou por maldição, não nos consideramos diante de um ponto final. A marca dos contrastes tornou-se visível, mas nunca se discutiu tanto sua solução. É claro que, na maioria das vezes, afunda-se apenas na retórica. Entretanto, neste mundo capitalista, a ação empresarial anuncia possibilidades de reversão desse quadro. Essa é a proposta da emergência da responsabilidade social. Ligado ao surgimento do terceiro setor, esse movimento desenvolvese a partir da proposta de uma "nova ordem social”, decorrente da falência do Estado enquanto provedor do bem-estar social e com base na reforma das relações do cidadão com o governo. Trata-se, portanto, não da cidadania legitimada pelo Estado, mas daquela obtida e assegurada por ações efetivas da comunidade, inserida num novo pacto social (Melo Neto, 2001).

Este trabalho pretende refletir sobre o espaço da empresa cidadã condutora da responsabilidade social no atual contexto da globalização. Entretanto, não serão discutidos seus deveres e direitos. Buscamos entender a inserção desse setor produtivo na necessidade de minimizar os graves problemas sociais da atualidade. Sendo assim, este estudo dividese em duas partes.

Na primeira parte, será feita uma breve análise desse movimento e de sua inserção na "nova ordem social”, a partir da ótica da complexidade como fundamental para fugirmos do pensamento simplificador tradicional (Morin, 2000). Cabe, ainda, compreender que, atualmente, falar em responsabilidade social é fazer a interseção de dois setores econômicos clássicos, o público, representado pelo Estado, e o privado, desempenhado pelo empresariado. Assim, o conceito de responsabilidade social aqui definido alinha-se com aquele do desenvolvimento sustentável apoiado no tripé dimensão econômica, dimensão social e dimensão ambiental. Por estarem assim interligados os setores econômicos e as dimensões de desenvolvimento, buscaremos, sob a perspectiva do pensamento habermasiano, discutir a emergência de novos interesses nesta "nova ordem social." Entendese como fundamental a junção do conhecimento objetivo e do conhecimento subjetivo a fim de transcender o campo das aparências ontológicas que as ciências, ideologicamente comprometidas, têm conduzido tradicionalmente. Nessa ótica, falar de movimentos sociais ou de suas organizações é falar dos homens que nelas vivem, de suas práticas e de seu simbólico, de sua razão, mas também de sua emoção. O empreendimento aqui proposto, portanto, 
desdobrar-se-á à luz dos conhecimentos da psicossociologia. A ênfase recairá sobre a contribuição que a psicanálise proporciona à leitura do que escapa ao discurso tradicional, positivista, presente em qualquer ordem organizacional, seja ela "nova" ou "ultrapassada". Assim sendo, "transcenderemos" a discussão da novidade para nos fixarmos na dualidade construção e destruição, sempre presentes no percurso da história da humanidade pelo Planeta. Avaliaremos o papel defensivo da idealização contra nossas forças destrutivas internas e os aspectos que, simultaneamente, se desdobram em benefícios - mas também em dificuldades - de vivência e de convivência conosco e com os nossos semelhantes.

Na segunda parte, a organização será nosso objeto de reflexão. Dois aspectos serão apreciados. Um considerará a responsabilidade como um processo em construção, e, como tal, "em estado nascente"; sendo assim, exige a compreensão dos princípios de sua formação (Enriquez, 1994). O outro observará a organização enquanto sistema cultural, simbólico e imaginário, cujos produtos circulam submetidos a diferentes níveis ou instâncias: mítica, sociohistórica, institucional, organizacional, grupal, individual e pulsional (Enriquez, 1997). Discutiremos a emergência da responsabilidade social enquanto mecanismo duplo do empresariado. Por um lado, alicerce de consciência política, social, cultural, econômica, ética e ambiental preocupada com a inserção social e a sustentabilidade da sociedade (Melo Neto, 2002); por outro lado, remissão da culpa pela destruição que seu sistema produtivo impõe à imensa maioria da humanidade.

\section{Complexidade e responsabilidade social: um grito contra a hegemonia da uniformidade.}

A responsabilidade social anuncia-se como algo novo. Em geral, títulos como "a nova onda muda a face das empresas" e “a responsabilidade social é uma tendência emergente” provocam a atenção do públicoalvo de reportagens, artigos e matérias sobre o assunto. Esse anúncio ecoa, acompanhado de outras "novidades": a "nova ordem mundial” da globalização, a "nova ordem social”, a "nova restruturação de trabalho" e até uma "nova ordem de pensamento". Vivese, portanto, no novo milênio, o anúncio da pós-modernidade e discutem-se os efeitos dela decorrentes sobre a sociedade. Polêmicas se erguem contra ou a favor dessas colocações, mas não é interesse deste trabalho entrar nessa discussão.

Antes, analisaremos a responsabilidade social como uma resposta empresarial aos problemas sociais atuais e às implicações que trazem à sua gestão. A responsabilidade social é, quase sempre, percebida como uma modificação da postura do empresariado. A idéia é a de transformar o objetivo de "negócio do negócio” para "negócio do social”, favorecendo a dinâmica social sustentável, motivadora de um empreendedorismo social (Melo Neto, 2002). Esse propósito, como qualquer outro, corre o risco de fracassar caso não esteja vinculado a profundas mudanças. De fato, o capitalismo cresceu alheio à complexidade inerente a qualquer sistema de produção e desconsiderou a união entre ordem e desordem como partes inseparáveis de sua evolução. Atualmente, o interesse do capitalismo em manter sua própria estabilidade levaria à necessidade de considerar as mazelas de sua conduta através de uma nova postura empresarial, marcada por ações socialmente responsáveis.

No entanto, em vez de nos deixarmos seduzir pelo anúncio da responsabilidade social vinculada à ótica da emergência do novo como uma "página virada" do capitalismo predatório, compreendemos a emergência da nova postura empresarial como um ciclo, onde fim e começo são partes contínuas de um mesmo processo, como abordado a seguir. 


\section{O horror à dissolução do eu na competição global}

Com a globalização, o mundo adormeceu com o sonho da construção e da paz entre as nações e acordou com o pesadelo da destruição e do aumento dos conflitos batendo à porta de cada habitante do planeta.

A competição pode ser de exploração, quando "ocorre indiretamente, através do uso de recursos compartilhados", ou pode ser uma competição de interferência, se "envolver interações diretas entre os

competidores sobre os recursos compartilhados."

Ricklefs
O mesmo mercado global que homogeneiza os modos de vida e de consumo do mundo espalha imensas frustrações, resultantes de desequilíbrios econômicos e demográficos entre os países. Dewitte (2003) avalia que essa situação está diretamente ligada ao questionamento da livre circulação das pessoas entre os países e da permissão para um liberalismo econômico aplicado à força de trabalho. Com isso, desencadeia-se “... uma concorrência feroz entre trabalhadores nacionais e imigrados, uma precarização acrescida do nível de vida de uns e outros e uma desestabilização das políticas sociais nos países desenvolvidos” (ibidem, p. 87).

No que tange à competição entre indivíduos da mesma espécie, Ricklefs (2003) apresenta uma diferença interessante, observada na natureza. A competição pode ser de exploração, quando "ocorre indiretamente, através do uso de recursos compartilhados”, ou pode ser uma competição de interferência, se "envolver interações diretas entre os competidores sobre os recursos compartilhados.” Nesse caso, a conseqüência maior é a agressividade entre os competidores da mesma espécie.

O homem, inimigo do próprio homem, luta por recursos como os outros seres o fazem. Entretanto, é bom reconhecermos que “... não se pode falar no mesmo fôlego de ratos $e$ homens, sem reconhecer claramente que o assunto da conversa mudou” (Asch, 1977, p. 5). Afinal, Charles Darwin não deve ter seu trabalho desmerecido. Muito pelo contrário! Como ignorar que descendemos de formas animais inferiores, tornando-nos, em conseqüência, superiores? Como esquecer nosso cérebro sofisticado, produtor de oxitocina, responsável pelas nossas emoções, as “forças ocultas e indomáveis que por vezes conseguem se sobrepor à vontade própria...” ((Damásio, 1996, p.150)? Somos, portanto, seres diferenciados dos outros animais. A percepção dessa realidade tornou-nos onipotentes, seguros da preferência de Deus, ou de vários Deuses, conforme a cultura. Desafiamos a destruição com nossa razão, nossa linguagem e nossa ação produtiva sobre a natureza. Entretanto, apesar de nosso desenvolvimento criativo, continuamos contraditórios, seres da destruição e da construção, ameaçados e beneficiados tanto por forças externas quanto por forças internas em constante conflito. Frente às forças destrutivas do aniquilamento, os homens encontram o horror à anulação e à dissolução de seu ser. A agressividade interna é externalizada, gerando a morte do outro. Freud denuncia essa angústia da humanidade quando escreve $O$ mal-estar da civilização, em 1930:

O sofrimento nos ameaça a partir de três direções: de nosso próprio corpo, condenado à decadência e à dissolução, e que nem mesmo pode dispensar o sofrimento e a ansiedade como sinais de advertência; do mundo externo, que pode voltar-se contra nós com forças de destruição esmagadoras e impiedosas, e, finalmente, de nossos relacionamentos com os outros homens. O sofrimento que provém dessa última fonte talvez nos seja mais penoso do que qualquer outro. Tendemos a encará-lo como uma espécie de acréscimo gratuito, embora ele não possa ser menos fatidicamente inevitável do que o sofrimento oriundo de outras fontes (p. 95).

O sofrimento, portanto, acompanha o homem, que vê ameaçado seu corpo, seu território, seu trabalho, sua família, se não pela natureza, pela mão de outro homem. Desse modo, a globalização, que coloca em marcha, sem fronteiras, uma grande massa de seres, mesmo que semelhantes, na disputa por um número cada vez menor de recursos (capital, trabalho, 
espaço, etc) intensifica o medo da dissolução, o esvaziamento total do eu, o retorno ao caos absoluto, a destruição do ser que luta pela sobrevivência.

Nesse sentido, a emergência da responsabilidade social corporativa pode ser compreendida como um movimento criativo da humanidade, visando a diminuir a destruição do sistema capitalista de produção, da qual ela é representante. Entretanto, também nesse caso, devemos ficar atentos à conjunção entre a ordem e a desordem. Não raramente, por exemplo, a mesma organização que acumula prêmios por suas ações de responsabilidade social contrata serviços terceirizados de empresas cujos empregados são mal remunerados e desrespeitados em seus direitos de cidadãos.

Morin (1982) observa que o mundo não se reduz à ordem ou à desordem. Isso seria o determinismo. A ordem liga-se às interações, enquanto a desordem remete ao acaso. Esta última comporta o objetivo e o subjetivo. O repúdio ao enfrentamento da destruição e dos conflitos se apresenta e se fortalece na organização científica do século XIX. A herança platônica legitima o discurso universal, a Verdade, “ ... cujo estatuto de universalidade é fundado no princípio da não-contradição" (Garcia-Roza, 1997, p.11). Desse modo, o objeto é facilmente extraído de seu contexto. Os laços que o relacionam com o meio, e com o sistema global do qual faz parte, podem ser cortados quando a ordem dominante for ameaçada. É a postura de uma ciência econômica construída como um sistema fechado. Morin (s/d) afirma que o princípio da ordem, o princípio da separação, o princípio da redução e o caráter absoluto da lógica dedutivo-identitária são os pilares da certeza científica.

Pagamos o preço do mau funcionamento de nossa existência com guerras, fomes, misérias, desgastes ambientais, sociais, físicos e emocionais, mas esperamos superá-los a cada instante, sem descartar o mesmo sistema lógico que os sustenta. Quantificamos dados e evitamos as “... transformações qualitativas ou as emergências que sobrevêm a partir das interações organizacionais” (ibidem, p. 98), imaginando impedir o caos, a desordem e a nossa própria destruição.

A ciência, ideologicamente parte desse mesmo sistema, não observou a complexidade dos fenômenos que estuda. Especializou-se ora na diversificação, ora na unificação do saber, de forma reducionista, sem privilegiar a simultaneidade entre ordem e desordem. Mas até quando podemos manter o saber separado, evitando unir diversidade e unidade? Até quando será possível viver responsavelmente, sem enfrentar a complexidade de nossas ações? O desgaste do meio ambiente, o desemprego em massa, o crescimento das populações e das megalópoles, o aumento da diferença entre ricos e pobres podem ser considerados à parte dos avanços tecnológicos, das divisões geopolíticas ou dos interesses das classes dominantes em manter suas posições hegemônicas? A institucionalização da lógica racional, que reduz um problema ao econômico, ou à luta de classes, ou ao desgaste da natureza, ou a tantas outras alternativas simplistas, ofusca a avaliação das forças de construção e de destruição da natureza e do existir humano.

É possível afirmar que, diante do medo de dissolução da humanidade, frente ao seu potencial destrutivo, iniciamos uma nova era? É preciso ser cauteloso quanto a isso. Podemos reconhecer a louvável intenção de envolver o empresariado na reparação pelo mal causado à natureza e de criar mecanismos que possibilite a ele continuar produzindo. Ainda é cedo para afirmar que a solução oferecida não está calcada na razão instrumental e na objetividade do discurso dominante. Nesse caso, observamos a reciclagem de antigas diretrizes que anunciam novas formas de
A ordem liga-se às interações, enquanto a desordem remete ao acaso. Esta última comporta o objetivo e o subjetivo.

Morin 
desenvolvimento, impondo os velhos modelos de dominação (Domingos, 1999). Para melhor conhecer esse quadro, é preciso, então, “...ter condições de penetrar nas aparências e conhecer o escondido - as verdadeiras causas - e não simplesmente trabalhar a superficialidade das operações sem questionamentos” (Moura, 1986, p.196).

O mundo dos negócios enfrenta dificuldades práticas, objetivas, mas as questões subjetivas de dominação e de controle, de inclusão e de exclusão, de glória e de ofuscamento não são questões secundárias. Diante dos dados concretos, construção e destruição são faces da moeda do sofrimento e da luta a favor e contra a dissolução do eu pela ação da condição biológica do homem, pela ação da natureza e pela interação entre os homens.

\section{O investimento do interesse capital: o convívio das diferenças sob o prisma da racionalidade instrumental}

A responsabilidade social corporativa propõese a articular variados segmentos (Estado, empresariado e comunidades) sociais, abrange múltiplas dimensões (econômica, social e ambiental), exige várias condutas (ética e cidadã) e envolve diferentes campos (cultural, simbólico e imaginário) da organização (Melo Neto \& Froes, 2002). A ambição de articular tal diversidade de forma democrática é sedutora, e conseguir fazê-lo equilibradamente seria um feito novo no mundo capitalista. Gephart \& all (1986) fazem uma análise interessante da organização social das sociedades tradicionais, das sociedades modernas e das sociedades atuais. Cada uma delas apresenta um modelo de autoridade particular, mas sempre marcado por relações de dominação.

Nas sociedades tradicionais, patriarcais, a autoridade era regulada pelo patrimônio. O Estado, conduzido pelo paternalismo, regulamentava o lar e a família. Os negócios não eram burocratizados. Em vez de documentos e de papéis, as negociações eram baseadas nas relações pessoais. A burocratização surgiu no modernismo clássico. A crença fundamental na resolução de problemas sociais estava associada à possibilidade de sua resolução racional, através da intervenção do Estado, e da aplicação de teorias científicas sociais. Imperavam a racionalidade técnica, a ética protestante e o “espírito capitalista”. Os problemas continuaram a existir! Com a república de Weimar, na Alemanha (1919-1933), entre o apogeu e a decadência, instalam-se os primórdios do Estado Moderno. Iniciava-se o imperativo organizacional. Todos, indivíduos e organizações, dirigidos para a eficácia e para a eficiência da produção. As organizações foram anunciadas como salvadoras da humanidade. Os males seriam curados pelo crescimento e pela prosperidade. Diante do Novo Senhor, cresceu a ética da obediência às decisões gerenciais, a administração feudal da produção e o darwinismo social. A transformação da sociedade atual, afirma Gephart, não constitui um progresso ou uma vantagem. O controle passou da racionalidade à submissão, do indivíduo ao coletivo. A realidade concreta foi transformada em realidade virtual. A natureza foi substituída por imagens. O humano tornouse coadjuvante da tecnologia. Eis o cenário atual!

O homem, descartável e substituível, tanto por máquinas quanto por outros homens, aparece vinculado à dinâmica da relação social dominante capitalista. Então, enquanto se procura um novo modelo de organização, assiste-se ao esvaziamento generalizado da natureza, do Estado e da humanidade, como que a suspender a morte e o caos que poderiam advir do homem imperfeito, e ao anúncio de um mundo melhor e mais potente, perfeita recriação da razão humana.

A criação de figuras ou de sistemas que simbolizem a organização de um mundo 
melhor é antiga. Zeus, por exemplo, para os gregos, simbolizava o reino do espírito. No entanto, para os antigos, a esperança de uma nova ordem não abandona a vida comum. As relações são hierarquizadas e definem traições e pactos, ambições e violência. Paixões e demônios existem lado a lado. Habermas (1983) analisa essa lógica da seguinte maneira: Essas imagens míticas, religiosas e metafísicas do mundo obedecem à lógica da contextura da interação. Elas dão respostas aos problemas centrais da humanidade, relativos à vida comum e à história da vida individual. Seus temas são justiça e liberdade, violência e opressão, felicidade e satisfação, miséria e morte. Suas categorias são vitória e derrota, amor e ódio, salvação e danação. Sua lógica se mede pela gramática de uma comunicação desfigurada e pela causalidade do destino, determinada por símbolos cindidos e motivos recalcados (ibidem, p. 314).

A divisória entre a sociedade tradicional e a sociedade moderna firma-se no avanço racional em detrimento das interpretações cosmológicas do mundo. Aquelas, obedientes à lógica da contextura da interação; estas, baseadas na "racionalidade de relações meiofim vinculada ao agir instrumental estratégico" (ibidem, p. 215). Nessa passagem, a técnica e ciência positivistas desapropriam as diferenças, os conflitos e os valores da interação social enquanto enaltecem as necessidades funcionais.

Moura (1986) esclarece que, na teoria habermasiana, a racionalidade tem dois níveis: o nível instrumental, ou técnico, e o nível da interação ou comunicação. No primeiro, destacam-se as regras técnicas surgidas do saber empírico. No segundo, as normas vinculam-se à mediação simbólica e são marcadas pelas expectativas dos comportamentos compartilhados. A ênfase no agir técnico em detrimento do agir comunicativo torna legítima a dominação. As decisões baseiam-se em regras técnicas, evitando a discussão em nível dos valores. Essa dinâmica destaca o autor e torna as organizações sociais de produção empobrecidas e cegas quanto às conseqüências de suas ações.

O modelo capitalista tradicional, baseado na razão instrumental e fortemente apoiado na burocracia tradicional, aspira ao "nivelamento das diferenças sociais” e ao fim dos privilégios através da impessoalidade (Weber, 1947). Entretanto, a identificação maciça com o discurso racional e a supressão da subjetividade geram o estreitamento do pensamento, induzem à compulsão à repetição e impedem a renovação da vida que jorra da diversidade e da espontaneidade.

Para Blackburn (1993), o materialismo histórico, com ênfase na produção econômica inspirada na fonte hegeliana e na economia política, induziu Marx ao erro, por limitar suas discussões apenas ao eixo do idealismo e ao eixo do materialismo. Com isso, o discurso circunscreveu-se apenas ao nível econômico, e não se exploraram outras propriedades destrutivas e criativas da natureza e do homem. Neste ponto, há que se esclarecer que a admissão da diversidade no sistema capitalista não gera automaticamente a resolução das contradições dela decorrentes.

A conjugação da diversidade na responsabilidade social é observada na parceria do Estado, do empresariado e das comunidades no campo social, na consideração das dimensões econômica, social e ambiental na área do saber técnico e na aceitação de condutas éticas e de cidadania, conjugadas ao reconhecimento dos campos cultural, simbólico e imaginário das organizações. Tudo isso ecoa para anunciar um novo paradigma. No entanto, com a globalização, enfrentamos a concentração de capital em oligopólios mundiais, um tecido social esgarçado pelas mazelas do capitalismo hegemônico que sobreviveu à Guerra Fria do final do século XX e um Estado ainda presente na economia e 
"Oligopólios

mundiais que dominam o seu sector, coabitando com milhares de empresas mais pequenas, mas cada vez mais multinacionais ou subcontratantes das grandes empresas do oligopólio"

Andreff na vida social, mas muito mais enfraquecido. Continuamos, portanto, presos à hegemonia capitalista. Gratos por essa sobrevivência, ignoramos, ou minimizamos, seu potencial de destruição. A esperança de superação de um fim firma-se nas conquistas tecnológicas ou na ilusão da grandeza mundial. Cansados, mas sem forças para reagir, voltamos repetitivamente à racionalidade instrumental e ao silenciar da subjetividade e da diversidade que alimentam as amarguras humanas. Não que isso seja recente, mas hoje as proporções catastróficas dessa hegemonia podem ser gigantescas. Vejamos a própria expansão da economia mundial. O aumento de fusões e de aquisições de empresas visava a globalizar a produção, a inovação, a ampliação de financiamento e do quadro de recrutamento diversificado de seus dirigentes. Serviu para criar "oligopólios mundiais que dominam o seu sector, coabitando com milhares de empresas mais pequenas, mas cada vez mais multinacionais ou subcontratantes das grandes empresas do oligopólio" (Andreff, 2000, p. 121). A Nova Ordem Global, teve, portanto, efeitos sobre os vários segmentos (Estado, empresas e as diversas comunidades mundiais), ao mesmo tempo em que, internamente, evocava a morte dos que acreditaram na possibilidade de compartilhar das riquezas do mundo.

De fato, afirma Morin (s/d), o progresso do conhecimento efetua-se "não pelo recuo ou dissolução, mas pelo reconhecimento $e$ afrontamento do irresolúvel” (ibidem, p. 121). Como no Totem e Tabu freudiano, os filhos, diante da impossibilidade de ocupar o lugar do Pai, unem-se, matando-o. Fazendo-o, recomeçam uma nova ordem: a fraternidade. Nesse sentido, firmada na dialética, a responsabilidade social pode surgir como uma possibilidade de ouvir os gritos horrorizados pelo sofrimento reducionista que o materialismo histórico tem imposto à humanidade. Se haverá possibilidade de, ao escutar atentamente tamanha dor, saná-la, já não nos cabe responder. Podemos, no entanto, fazer ecoar a dor e ouvir a dívida simbólica e a responsabilidade de sujeitos acometidos de culpa perante seus próprios males e os males de seus pares. É nossa intenção fazê-lo na próxima parte deste trabalho.

\section{Responsabilidade social corporativa: benevolência ou culpa?}

No campo da responsabilidade social, o exercício da cidadania empresarial amplia-se a cada ano, valorizando a imagem da empresa perante o consumidor, o público interno e a sociedade em geral, ajudando, por tabela, o mundo dos negócios a se fortalecer, uma vez que um mundo em colapso não promove uma boa situação para as finanças.

Melo Neto \& Froes (2001) observam que, na verdade, o agravamento dos problemas sociais e ambientais no mundo globalizado tem gerado uma mudança de postura no meio empresarial. Até poucas décadas atrás, as grandes corporações se preocupavam em oferecer serviços e produtos a seus clientes. Seus acionistas faziam filantropia de forma individual, elegendo ações sociais e alocando recursos de forma pontual e isolada.

Hoje, a relevância, a gravidade e a complexidade dos problemas sociais e ambientais no mundo todo exige soluções rápidas, precisas e viáveis, com o envolvimento da comunidade e a participação do governo e do setor privado. O empresariado participa colocando à disposição da sociedade seus recursos financeiros, tecnológicos e econômicos para promover melhoria na qualidade de vida da população humana.

Assim, aproveitando seu conhecimento e organização, as boas ações deixam de ser atos pontuais ou iniciativas particulares nos relatórios anuais das empresas, para se transformar em poderosos instrumentos de melhoria de 
gestão. Exemplo concreto dessa realidade é a divulgação de balanços sociais, onde grandes corporações analisam suas conquistas e deficiências de maneira transparente. Assim, além de divulgar à sociedade seus esforços na área de responsabilidade social, elas também podem estabelecer metas e estratégias de melhoria contínua de suas ações. Mas, colocado dessa maneira, não teríamos, nessa "nova” posição, o mesmo vício da razão instrumental anteriormente discutida? O que significa, afinal, responsabilidade social?

Responsabilidade social é uma composição redundante. Ser responsável, do latim responsabile, é a qualidade daquele que é responsável, mas é também a obrigação geral de responder pelas conseqüências dos próprios atos ou pelas dos outros. O ser responsável está, portanto, automaticamente ligado ao outro, dá conta de seus atos públicos, assume os efeitos de suas ações e estas são sempre da ordem do social, da alteridade entre o eu e o outro, ou seja, a responsabilidade é sempre social. Portanto, as ações das corporações estão automaticamente inseridas numa responsabilidade social. Mas ser responsável é também ser culpado de algum crime, ser causador de alguma coisa. Surge uma questão! De quê as corporações são causadoras? Que crimes cometeram? Do quê são acusadas, afinal? Olhar para o campo no qual elas pretendem atuar, com suas ações de responsabilidade social, dar-nos-á dará pistas de possíveis respostas a essas perguntas. A responsabilidade social corporativa faz parte de uma tentativa das empresas de pagar uma dívida para com a sociedade. Há pelo menos dois desdobramentos possíveis nesse pagamento. Um relaciona-se ao fato de que, há algumas décadas, discute-se, na Europa, a questão de as empresas consumirem recursos naturais, renováveis ou não, que são patrimônio da humanidade. Nesse caso, o desempenho da empresa depende da utilização dos recursos naturais, mas, ao usufruílos em benefício próprio, ela contrai uma dívida social para com a sociedade (Melo Neto \& Froes, 1999). O outro decorre da existência de uma parte considerável da sociedade à margem das graças propostas pelo capitalismo. As empresas encontram-se suspensas num movimento duplo. São consumidoras irresponsáveis e agentes das agonias sociais e, simultaneamente, são salvadoras do equilíbrio social. Afinal, elas geram empregos e renda para os habitantes de um determinado espaço (físico ou não), produzem tecnologia e negócios que garantem a subsistência de uma parte da população e, agora, exigem também o título de agentes de desenvolvimento social. É a partir do conceito de dívida social, e de um quadro de carências sociais concreto, que elas encontram os elementos definidores dos projetos sociais. Por sua vez, a ação empreendida pela empresa insere-se numa cadeia de valor social empresarial que é divulgada em forma de balanço social e de marketing para consumidores conscientes e acionistas cumpridores de seus deveres de cidadãos. Portanto, aqueles que provocam a dor da exclusão encontram, nas ações sociais, o alívio para o quadro de angústia e de sofrimento humano imposto pela cadeia produtiva capitalista globalizada. Fecha-se um ciclo que tenta resgatar os efeitos perversos de um sistema dominante, mas não mais sustentado como livre de falhas, de dores e de horrores para a grande maioria daqueles que a ele são submetidos.

Não se esconde mais que o capitalismo, a máxima empresarial, tem sido responsável por profundos desequilíbrios na vida humana no planeta. Desde a revolução industrial, no século XVIII, até sua soberania, com o fim da Guerra Fria, sua ascensão está direta ou indiretamente ligada tanto aos avanços quanto às maiores crises da humanidade. Tomemos, por exemplo, a recente combinação entre a tecnologia e a genética. Por um lado, a tecnologia permite a comunicação rápida pelos quatro cantos do mundo e facilita avanços em várias áreas do conhecimento, e a genética 
"não se trata de um delito moral. 0 sofrimento é

devido a um erro de julgamento (amartia)" reinventa a criação da Natureza e faz o homem recodificar o mundo. Por outro lado, esse mesmo avanço é responsável pela destruição das fronteiras entre as espécies, entre as pessoas e as coisas, entre o vivo e a matéria (Vandelac, 2000). O avanço tecnológico abraça-se mortalmente à destruição da biodiversidade.

Nesse ponto, a lógica que opera na razão instrumental do mundo ocidental, após a revolução industrial, atinge o seu ponto máximo. Verifica-se a negação da alteridade, da diversidade da vida, justificada pela racionalidade dos meios utilizados em relação aos fins desejados e decididos, a adequação dos meios aos fins, a partir de um cálculo custo/ benefício, referido tão somente a elementos mensuráveis; a vida é situada fora das equações, desconsiderada, renegada. Os dados da realidade, racionalizados individualmente, transformam-se em ideologia, coletivamente, alimentando “... a força do interesse que penetra no núcleo lógico da pesquisa (Habermas, p. 299) e ignoram a subjetividade. Os economistas favorecem a elaboração de indicadores sociais ou humanos que poderão entrar nesse cálculo, mas seus indicadores, presos pela racionalidade instrumental, ocultam a referência social (mesmo diretamente, operante na escolha e na construção das variáveis) e a ética (Enriquez,1995).

A empresa cidadã, preocupada com a responsabilidade social, está circunscrita num terrível dilema. Direciona sua ação para a minimização dos excluídos e marginalizados do desenvolvimento social, o que é bastante positivo, mas está presa a uma cadeia positivista racional que despreza o valor da vida e considera a desordem um bem supremo, gerador do continuum existencial. Ferreira Neto (1998) observa que, na Bíblia, a idéia de culpa aparece logo nos primórdios da Criação, na ira de Deus contra Adão e Eva. Numa interessante contradição, o Criador ordena que eles se multipliquem e expulsa-os do Paraíso por seguirem seus desejos. Diz o autor que a interdição divina fundou o recalque, e o recalcado retornou logo na primeira geração. O primeiro filho do mundo, Caim, por um processo de deslocamento, substituiu a perplexidade original por uma atuação. Ao matar seu próprio irmão, fabricou um motivo concreto para justificar a culpa (ibidem, p. 72).

Também a culpa original acompanha o homem no cristianismo, transmitindo-se de geração em geração, sentida na própria pele. Na tradição grega, não existia o conceito de livre-arbítrio. O desejo do homem estava sujeito ao desejo dos deuses, mas nem assim, enquanto mero instrumento dos deuses, o homem pôde ser absolvido da culpa. A justificativa para isso, afirma o autor, "não se trata de um delito moral. O sofrimento é devido a um erro de julgamento (amartia)" (ibidem, p. 75) Portanto, a culpa não pode ser evitada. Na trilogia de Sófocles, Édipo procura o oráculo de Tirésias para conhecer a sua tragédia. Diante da Verdade, não consegue evitá-la, e mergulha na cegueira porque desrespeitou a Lei com a morte do pai e com o incesto com a mãe. Algo da ordem do impossível de ser reparado, por já haver sido consumado, obriga-o a viver na culpa até o resto de seus dias em Colono.

É importante destacar que Édipo, em Colono, diferentemente das outras peças, não termina em desgraça, e "sim, em reconciliação entre herói feliz e os deuses, com a mudança de “má sorte” para “boa sorte” (Kury, 1998, p.13). Possivelmente, isso se refere ao fato de Édipo, mesmo com muito sofrimento, ter escapado da morte trágica que acontece nos mitos gregos com tanta freqüência. Em Colono, Édipo, como sabemos, está cego, mas a imagem mítica possui duplo sentido, com "duas significações diametralmente opostas, completando-se pela analogia de contraste..." (Brandão, 1995, p.285). Do ponto de vista simbólico, a cegueira de Édipo possui um sentido mais profundo, já que as trevas formam a luz interna. 
Por analogia, e amparados por essa idéia, é possível reconhecer que, das trevas impostas pelo capitalismo, pode emergir a luz reparadora da culpa, expressa na responsabilidade social corporativa, mas não devemos fechar o raciocínio tão rapidamente. Essa ação deve representar, como qualquer outra, prenúncio benéfico e ameaça. Em Colono, Édipo refugiou-se com Antígona, sua filha, no bosque das Eumênidas, deusas que são complementares às Erínias. Ambas representam a culpa, mas enquanto estas são a culpa recalcada e destrutiva do tormento e do remorso, aquelas são de outra ordem. São a culpa mais conscientizada e assumida, convertida em sublimidade produtiva e arrependimento libertador... o simbolismo que substitui aquele dos olhos furados assinala, pois, que o doente da alma, o neurótico, cego pelo recalque, atormentado pela culpa, perseguido por Erínias, não pode curar-se a não ser que se torne cego para as seduções e se conscientize da culpa (ibidem, p. 285).

Cego para as seduções e consciente de sua culpa, Édipo pode, enfim, simbolicamente, libertar-se, transformar sua "má sorte" em "boa sorte”, o que significa afirmar que ele não se viu livre da culpa. Pelo contrário, durante toda a peça, ele é perseguido pelo Coro e por Creonte, instâncias superegóicas a massacrar sua existência, lembrando-o do incesto, culpando seus atos criminosos: a morte do pai e o desposar da mãe. Para aqueles que habitam fora do mito, não é diferente o caminho da culpa. Bauman (1999) observa que a culpa dos verdadeiros habitantes globais, em oposição aos que permaneceram locais, acalma-se na racionalidade e torna cristalina a consciência daqueles que mantêm a estagnação da dinâmica social.

É tão difícil negar aos pobres e famintos, sem se sentir culpado, o direito de ir onde há abundância de comida, e é virtualmente impossível propor argumentos racionais convincentes provando que a migração seria para eles uma decisão irracional. O desafio é realmente espantoso: negar aos outros o mesmíssimo direito à liberdade de movimento que se elogia como a máxima realização do mundo globalizante e a garantia de sua crescente prosperidade... (ibidem, p. 84).

Não há, nesse caso, uma consciência que conduza ao arrependimento libertador e à sublimação do impulso destrutivo. Para os culpados que tudo vêem, não existe a transformação. Alimentados pela ilusão do rompimento das fronteiras globais ou pela sedução da virtualidade, eles negam a castração e lutam para não renunciar à sua satisfação pulsional. Não se dão conta, pobres mortais, de que o preço dessa negação pode ser enlouquecedor!

Em 1923, no texto O Ego e o Id, Freud observa a culpa como o representante intrapsíquico das normas que permeiam a conduta do sujeito na sociedade. Sua origem, observa Corrêa (1998), ficaria nas discrepâncias entre o Superego e o Ego, ou entre este último e o Ideal de Ego. Com medo de perder a proteção da autoridade externa, opera-se a construção de uma autoridade interna e a renúncia pulsional. Nesse ponto, "há uma equivalência entre os maus atos e as más intenções, vindo daí o sentimento de culpa e a necessidade de punição" (ibidem, p. 41). Nessa construção, diante do Superego sádico, sofre o Ego masoquista. O homem está fadado a viver sua existência padecendo dessa contradição. Impedido de ter completude, sofre pelo desejo desse desejo. Investigando como a religião discursa sobre esse conflito, Ferreira Netto (1998) admite:

Não é nada que fizemos de mal ou de mais, é algo da ordem do menos, da falta, ausência, desamparo, impotência, desengano, transitoriedade, angústia, tédio, náusea, fraqueza, vazio, nostalgia, saudade do futuro, buraco, nada, perda, carência, exílio, imprevisibilidade, ressentimento, "ódio a Deus", indignação, injúria, sofrimento trágico e uma dor que, às vezes, pode ser mortal. Nada disso é sinônimo de culpa, nem, necessariamente, sua causa (ibidem, p. 81).

Portanto, como Édipo, o homem deve permanecer cego diante do desejo, mas, como 
ele não poderá deixar de desejar, amarrado a essa situação, oferecerá como pagamento o sofrimento, marcando sua importância perante o poder ilimitado de uma Lei Suprema.

A culpa tem valor psíquico fundamental para aquele que renuncia aos seus instintos, sendo uma maneira de resguardá-lo de pagar o preço da castração. Nesse sentido, a culpa pode ter um "efeito curativo, funcionar como "anticorpo psíquico”, a nos proteger do vírus da castração e da morte, fazendo-nos crer que somos nós os seus autores, aceitando-as melhor assim, como se não fossem uma impostura do Outro" (ibidem, p. 81).

Nessa lógica, a culpa que direciona as ações do empresariado para a responsabilidade social pode ter efeito curativo no sentido de nos tirar das trevas da hegemonia e da intolerância diante da diversidade. Entretanto, para que isso aconteça, é necessário que se aceitem as trevas em que nos encontramos mergulhados.

\section{Conclusão}

Ao discutir a responsabilidade social nas organizações, é imperativo considerar a complexidade do sistema capitalista, no que ele possui enquanto manutenção das ordens e das desordens que assolam a humanidade. Obviamente esse não é um passo simples. Marcado pela competição, o momento atual intensifica o medo da dissolução impresso em nosso ser vulnerável por natureza e proclama a necessidade de superação de um modelo predatório de produção justificado pelo reducionismo materialista histórico. A responsabilidade social das organizações, nesse caso, confirmaria ações concretas de uma nova postura do capitalismo. No entanto, é importante abandonar os vícios da racionalidade instrumental, objetiva, ignorante, da subjetividade. $\mathrm{O}$ reconhecimento da benevolência empresarial, transformada em ações de responsabilidade social, envolve mais do que o simples reconhecimento do poder de uma elite capitalista sobre a parte mais fragilizada da sociedade. Ela é a manifestação da culpa, enquanto “anticorpo psíquico” revelador das desordens que acompanham a onipotência decisória que aniquila, por exemplo, as possibilidades de uma organização de trabalho sobre seus trabalhadores ao desvalorizar os seus interesses. Habermas (1983) afirma não existir o conhecimento desinteressado. Os interesses estão a serviço da sobrevivência, da interação social e da construção de identidade humana. Moura (1986) descreve os três níveis de interesse do pensamento habermasiano:

1) Interesses técnicos ou instrumentais: visam a atender as necessidades materiais e físicas, através do trabalho, a fim de dominar e controlar as forças da natureza;

2)Interesses comunicativos: buscam significados na interação humana. Surgem da necessidade de segurança entre os homens e representamse no estabelecimento de pactos através da mediação da linguagem e da comunicação;

3)Interesses emancipatórios: reguladores dos outros interesses já que orientam o homem para a transcendência determinista da natureza e das leis sociohistóricas do seu próprio desenvolvimento.

Nessa lógica, os interesses emancipatórios só poderão ser atingidos através do consenso. Sugere-se, então, que a busca de acordos seguros para a convivência humana deve, obrigatoriamente, compreender a comunicação em sua totalidade. Impõe-se, assim, a consideração da transcendência dos fatos e o reconhecimento da subjetividade negligenciada nas negociações coletivas. Nessa integração, será possível reconhecer as coações presentes na natureza interna e externa que circunscrevem a existência da humanidade e, por extensão, qualquer sistema de produção por ela criado, inclusive aquele denominado atualmente responsabilidade social corporativa. 
Maria de Lurdes Costa Domingos Psicóloga, graduada pela UFRJ. Especialista em Psicologia clínica (PUC/RJ) Mestre em Psicossociologia de Comunidades e Ecologia Social (UFRJ). Doutoranda em Psicologia social (UERJ) Rua General Mariante, 138/601 Laranjeiras - Rio de Janeiro/RJ

CEP:22221-100

BLACKBURN, R.J. O Vampiro da Razão: um Ensaio de Filosofia da História. São Paulo: UNESP, 1992.

CAIRNCROSS, F. Meio Ambiente: Custos e Benefícios. São Paulo: Nobel, 1992.

DAMÁSIO, A.R. O Erro de Descartes: Emoção, Razão e o Cérebro Humano. São Paulo: Companhia das Letras, 1996.

DOMINGOS, M. Nosso Presente Incomum: Transformações e Reações Seladas nas Normas Ambientais ISO 14000. Dissertação de Mestrado em Psicossociologia de Comunidades e Ecologia Social. CFCH/EICOS, Universidade Federal do Rio de Janeiro, Rio de Janeiro, 1999.

FREITAS, M. E. Cultura Organizacional: Identidade, Sedução e Carisma? Rio de Janeiro: Ed. FGV, 1999.

GEPHART, R. \& al. Postmodern Management and Organization Theory. London: Sage Publications, 1986.

HARA, F. Cinqüenta Milhões de Refugiados e de Deslocados Vivem numa Precariedade Permanente. In: Cordellier, S. O Novo Estado do Mundo. Portugal: Campo das Letras Ed., 2000, pp. 46-49.
MELO NETO, F. P. de FROES, C. Empreendedorismo Social: a Transição para a Sociedade Sustentável. Rio de Janeiro: Qualitymark, 2002.

MORGAN, G. Imagens da Organização. São Paulo: Atlas, 1996.

MOURA, W. O Paradigma Frankfurteano: uma Alternativa para a Psicologia Organizacional. Tese de Doutorado em Psicossociologia. Instituto Superior de Estudos e Pesquisas Psicossociais, FGV, ISOP/CPGP, Rio de Janeiro, 1986.

RICKLEFS, R.E. A Economia da Natureza. 5 ed., Rio de Janeiro: Guanabara Koogan, 2003.

VANDELAC, L. A “Life Industry” TentaApropriar-se do Patrimônio Genético do Planeta. In: Cordellier, S. O Novo Estado do Mundo. Portugal: Campo das Letras Ed., 2000. pp 43-46.

VERNANT, J.P. O Universo, os Deuses, os Homens. São Paulo: Companhia das Letras, 2000. 